Published July 2019

EKONOMIKAWAN : Jurnal Ilmu Ekonomi dan Studi Pembangunan

ISSN : 1693-7600 (Print), ISSN : 2598-0157 (Online), http://jurnal.umsu.ac.Id/index.php/ekawan

\title{
Ekonomi Regional : Tipologi dan Sektor Potensial Dalam Pengembangan Wilayah (Studi Pada Wilayah Kecamatan di Kabupaten Jember)
}

\author{
Herman Cahyo Diartho
}

Fakultas Ekonomi dan Bisnis Universitas Jember,

Gg.5, Tegal Boto Lor, Sumbersari, Kec.Sumbersari, Kabupaten Jember, Jawa Timur 68121 e-mail : hermancahyodiartho@yahoo.com

\begin{abstract}
ABSTRAK
Tujuan penelitian yang dilakukan di Kabupaten Jember adalah untuk mengembangkan ekonomi wilayah kecamatan di Kabupaten Jember dengan mengidentifikasi tipologi dan sektor berpotensial serta menganalisis kontribusi dari sektor tersebut. Data sekunder time series yang bersumber dari BPS Kabupaten Jember tahun 2014-2017 berperan sebagai penunjang penelitian ini. Analisis tipologi klassen, DLQ dan Shift Share Esteban Marquillas akan digunakan sebagai alat analisis untuk mendapatkan hasil yang akan diuraikan pada bab pembahasan. Hasil analsis data menggunakan ketiga alat tersebut menghasilkan bahwa Kecamatan Kaliwates, Sumbersari dan Patrang merupakan wilayah cepat maju dan cepat tumbuh. Akhir tahun 2014 menunjukkan bahwa Kecamatan Puger Wuluhan, Ambulu, Tanggul, Bangsalsari dan Sumberbaru jika dilihat dari pertumbuhan PDRB yang terus meningkat beberapa wilayah tersebut masuk dalam kategori kuadran I. Wilayah yang masuk dalam kategori daerah tertinggal adalah Kecamatan Panti. Hasil penelitian menggunakan analisis DLQ menunjukkan bahwa sektor bangunan memiliki keunggulan dari pada sektor lain dan sektor yang dahulunya basis pada masa yang akan datang tetap berpotensial adalah sektor pertanian. Hasil analisis terakhir menggunakan analisis SSEM menghasilkan bahwa Kecamatan Jombang merupakan daerah analisis yang memiliki tujuh sektor yang memiliki keunggulan kompetitif.
\end{abstract}

Kata Kunci : DLQ, SSEM dan Tipologi Klassen. 


\title{
Regional Economy: Typology and Potential Sectors in Regional Development (Study in District Areas in Jember Regency)
}

\begin{abstract}
The purpose of research conducted in Jember is to develop the economic area of Kecamatan in Jember district by identifying potential typologies and sectors as well as analyzing the contributions of the sector. Secondary time series Data sourced from the BPS Jember District in 2014-2017 serves as supporting the research. Analysis of classical typology, DLQ and Shift Share Esteban Marquillas will be used as an analysis tool for obtaining the results to be outlined in the discussion chapter. The results of data analysis using these three tools resulted that the districts of Kaliwates, Sumbersari and Patrang are rapidly advancing and fast growing areas. The end of the year 2014 showed that Puger Wuluhan, Ambulu, Tanggul, Bangsalsari and Sumberbaru districts were seen from the growth of PDRB, which has continued to increase in the category of quadrants I. Areas that fall into the category of regions Left is Panti subdistrict. The results of the study using $D L Q$ analysis showed that the building sector has the advantage of other sectors and sectors that are in the future remain potential agricultural sectors. The latest analysis results using SSEM analysis resulted that Jombang subdistrict is an analysis area that has seven sectors that have a competitive advantage.
\end{abstract}

Keyword: DLQ, Shift Share EM and Typology Klassen

\section{PENDAHULUAN}

Pembangunan adalah usaha mengentas dan menstabilkan berbagai permasalahan yang dialami suatu daerah atau negara seperti kemiskinan dan pendapatan yang tidak stabil dengan tujuan akhir meratakan kesejahteraan dan peningkatan sumber daya untuk dimanfaatkan dengan maksimal (Todaro, 2000:123). Apabila pembangunan suatu negara ditekankan pada pembangunan ekonomi, maka pembangunan ekonomi dapat mendorong suatu perubahan-perubahan dalam bidang ekonomi untuk mencapai tujuan tertentu.

Sumber daya alam dan manusia serta kesejahteraan dijadikan sebagai prioritas utama untuk pembangunan ekonomi daerah bagi negara berkembang dengan menemukan daerah yang memiliki potensi untuk dikembangkan lebih lanjut. Menurut Royat (1996) dalam Mudrajad Kuncoro (2002:28) wilayah yang diandalkan sebaga pendorong utama perekonomian daerah berkriteria bertumbuh lebih cepat, memiliki sektor yang masuk dalam kategori basis serta berkaitan dengan ekonomi daerah lain. Perbedaan wilayah berarti menandakan perbedaan sumber daya alam, sumber daya manusia yang mempunyai keterbatasan dan hambatan dari pemerintah akibat akses lingkungan yang berbeda. Perbedaan tersebut mempengaruhi keberhasilan pemerintah dalam memajukan perekonomian suatu daerah. Peningkatan perkeonomian suatu daerha dapat dibantu dengan peran pemerintah sebagai sarana untuk mencari dan menemukan potensi suatu daerah sehingga dpat menciptakan peluang bagi masyarakat dan merangsang perluasan lapangan kerja. 
Published July 2019

EKONOMIKAWAN : Jurnal Ilmu Ekonomi dan Studi Pembangunan

ISSN : $1693-7600$ (Print), ISSN : 2598-0157 (Online), http://jurnal.umsu.ac.ld/index.php/ekawan

Perbedaan kecepatan suatu wilayah dalam mengembangkan kegiatan perekonomiannya untuk meningkatkan pertumbuhan ekonomi membuat ketidakmerataan ekonomi. Ketidakmerataan perekonomian tiap wilayah tersebut mengakibatkan siklus ekonomi macet sehingga susah untuk menstabilkan kembali. Pengelompokan wilayah untuk mengetahui wilayah yang memiliki kemajuan cepat dan lambat dapat menggunakan tipologi klassen dengan bantuan PDRB dan laju pertumbuhan (Sjarifal, 1997;27-38).

Kabupaten Jember merupakan salah satu wilayah di Jawa Timur yang mempunyai lahan seluas 3.293,34 $\mathrm{km}^{2}$ dan 31 kecamatan. Kecamatan Tempurejo merupakan wilayah yang memiliki lahan paling luas sedangkan Kecamatan Sumbersari merupakan wilayah yang berpenduduk paling banyak yaitu 126.279 jiwa.

Tristanto (2013) dalam penelitiannya menyatakan bahwa jika potensi yang dimiliki suatu daerah lebih besar dari pada daerah lain akan menyebabkan rangsangan pada daerah lain sehingga pertumbuhan ekonomi melalui sektor ekonomi akan lebih meningkat serta akan membantu sektor lain yang masih tidak nampak akan semakin berkembang. Sektor perekonomian suatu daerah ada beberapa yang tidak berpotensi dan ada yang potensinya mendominan sehingga dengan adanya pembangunan ekonomi diharapkan agar terjadinya pemerataan perkembangan pada keseluruhan sektor perekonomian di suatu daerah. Pemerataan secara keseluruhan ini akan membantu sektor yang paling berpotensi agar dapat bersaing dengan sektor ekonomi lain pada daerah sekitar. Kabupaten Jember memiliki tiga sektor yang berkontribusi paling banyak bagi PDRB yaitu pertanian; perdagangan, hotel dan restoran serta industri pengelolahan dengan masing-masing mengalami pertumbuhan sebesar $36,75 \% ; 26,13 \% ; 10,55 \%$. Ketiga sektor ini membantu dalam perencanaan pembangunan daerah di Kabupaten Jember. Sektor lain yang memiliki potensi untuk berkembang adalah sektor keuangan, sewa dan jasa perusahaan; pengangkutan dan komunikasi.

Tahun 2018 pemerintah Kabupaten Jember membuat RKPD untuk mengentas permasalahan yang menghambat pertumbuhan ekonomi dikarenakan pendapatan setiap Kecamatan rendah dengan cara mengeluarkan kebijakan. Kebijakan tersebut diberlakukan dengan tujuan meningkatkan persentase angka pertumbuhan daerah sehingga membantu dalam mengembangkan potensi daerah yang akan merangsang para investor luas menanamkan modalnya di daerah tersebut.

\section{METODE}

Penelitian ini menggunakan data sekunder yang diperoleh dari Badan Pusat Statistik Kabupaten Jember (BPS) ataupun instansi terkait yang menyediakan data untuk penelitian ini. Ada beberapa data nantinya yang akaN digunakan yaitu PDRB perkapita, laju pertumbuhan ekonomi dan PDRB pada tiap Kecamatan Kabupaten Jember. Analsis pertama dalam penelitian ini adalah tipologi klasen yang berfungsi mengelompokkan struktur perekonomian masing-masing daerah ke dalam kategori berupa kuadran I, II, III, dan IV. 
Published July 2019

EKONOMIKAWAN : Jurnal Ilmu Ekonomi dan Studi Pembangunan

ISSN : 1693-7600 (Print), ISSN : 2598-0157 (Online), http://jurnal.umsu.ac.Id/index.php/ekawan

Tabel 1. Pengelompokan Kabupaten/Kota menurut Klassen Typology

\begin{tabular}{|c|c|c|}
\hline $\begin{array}{c}\text { PDRB Perkapita (y) } \\
\text { Laju Pertumbuhan } \\
\text { PDRB (r) }\end{array}$ & Yi >y & Yi <y \\
\hline Ri $>$ r & $\begin{array}{c}\text { Kuadran I } \\
\text { Daerah maju dan tumbuh } \\
\text { cepat }\end{array}$ & $\begin{array}{c}\text { Kuadran II } \\
\text { Daerah maju tapi tertekan }\end{array}$ \\
\hline $\mathrm{Ri}<\mathrm{r}$ & $\begin{array}{c}\text { Kuadran III } \\
\text { Daerah berkembang cepat }\end{array}$ & $\begin{array}{c}\text { Kuadran IV } \\
\text { Daerah tertinggal }\end{array}$ \\
\hline
\end{tabular}

DLQ berfungsi untuk menentukan sektor yang masuk dalam kategori basis dan non basis di masa yang akan datang (Suyanto, 2000).

$$
D=\frac{1+g / 1+g}{1+G / 1+G}
$$

DLQ : Indeks dari laju pertumbuhan sektor ekonomi (i) di Kecamatan

Gij : rata-rata laju pertumbuhan PDRB sektor ekonomi (i) di Kecamatan

$\mathrm{Gj} \quad$ : rata-rata laju pertumbuhan PDRB Kecamatan

$\mathrm{Gi}$ : rata-rata laju pertumbuhan PDRB sektor ekonomi (i) di Kab.Jember

GJ : rata-rata laju pertumbuhan PDRB Kab.Jember

Apabila DLQ lebih besar dari satu maka pertumbuhan sektor yang dianalisis terhadap PDRB daerah tersebut masih bisa masuk dalam kategori basis di masa depan sebaliknya jika DLQ lebih kecil dari satu maka sektor tersebut tidak dapat menjadi basis di masa depan. Terakhir, apabila DLQ sama dengan satu maka laju pertumbuhan sektor tersebut terhadap pertumbuhan PDRB daerah $\mathrm{n}$ sebanding.

Esteban Marquillas (1972) memodifikasi shift share yang memiliki unsur baru E'ij yang merupakan variabel wilayah (Eij) (Soepono, 1993:47). Perumusan unsur baru jika struktur wilayah sama dengan nasional adalah sebagai berikut:

$$
E^{\prime} i i=E(E / E) a \quad C=E\left(r_{i}-r_{i}\right)
$$

Menurut shift share, $\mathrm{Cij}$ merupakan notasi yang digunakan untuk mengukur keunggulan suatu sektor ekonomi wilayah. Laju pertumbuhan memiliki notasi-notasi yang dapat diartikan sebagai berikut:

a. Pengukuran laju pertumbuhan dari sektor tertentu dari wilayah yang bersangkutan yang akan dianalis (j) rij $=\left(E^{*} \mathrm{ij}-\right.$ Eij $) /$ Eij

b. Pengukuran laju pertumbuhan dari sektor tertentu dari wilayah yang dijadikan sebagai acuan $\operatorname{rin}=\left(\mathrm{E}^{*}\right.$ in-Ein $) /$ Ein

c. Pengukuran laju pertumbuhan dari wilayah yang dijadikan sebagai acuan $r n=\left(E^{*} n-\right.$ En)/En 
Published July 2019

EKONOMIKAWAN : Jurnal Ilmu Ekonomi dan Studi Pembangunan

ISSN : 1693-7600 (Print), ISSN : 2598-0157 (Online), http://jurnal.umsu.ac.Id/index.php/ekawan

Keterangan:

$E^{*}$ in : PDRB sektor i ditingkat wilayah referensi pada tahun akhir analisis

Ein : PDRB sektor i ditingkat wilayah referensi pada tahun awal analisis

$\mathrm{E}^{*} \mathrm{n}$ : PDRB wilayah referensi pada tahun akhir analisis

En : PDRB wilayah referensi pada tahun awal analisis

$$
A j=\left(E-E^{\prime} i i\right)(r,-r)
$$

di mana (Eij-E'ij) merupakan tingkat spesialisasi sektor tertentu dari wilayah yang akan dinalisis (Kabupaten Jember); (rij-rin) merupakan tingkat keunggulan kompetitif sektor tertentu dari wilayah yang akan dianalisis (Kabupaten Jember) dan Aij berperan menjadi pengaruh alokasi dengan melihat perkalian antara tingkat spesialisasi dan keunggulan kompetitif. berikut:

Perubahan rumus alat analisis Shift Share menjadi SSEM dapat dilihat sebagai

$$
\operatorname{Dij}=\operatorname{Eij}(r n)+E i j(r i j-r n)+E i j(r i j-r i n)+(E i j-E i j)(r i j-r i n)
$$

Sektor $\mathrm{n}$ akan memperoleh kemungkinan dampak positif dan negatif dari efek alokasi apabila spesialisasi dari sektor tertentu yang ada di daerah tersebut memiliki keunggulan kompetitif (lihat Tabel 2).

Tabel 2. Kemungkinan Efek Alokasi

\begin{tabular}{|c|l|c|c|}
\hline \multirow{2}{*}{ No } & \multicolumn{1}{|c|}{ Kriteria } & \multicolumn{2}{|c|}{ Komponen } \\
\cline { 3 - 4 } & & $\left(\mathrm{E}_{\mathrm{ij}}-\hat{\mathrm{E}}_{\mathrm{ij}}\right)$ & $\left(\mathrm{r}_{\mathrm{i}}-\mathrm{R}_{\mathrm{i}}\right)$ \\
\hline 1 & Competitive disadvantage, spesialized & + & - \\
\hline 2 & Competitive disadvantage, notspesialized & - & - \\
\hline 3 & Competitive advantage, notspesialized & - & + \\
\hline 4 & Competitive advantage, spesialized & + & + \\
\hline
\end{tabular}

\section{HASIL DAN PEMBASAHAN \\ Hasil Analisis Data}

Tipologi Klassen mengklasifikasikan wilayah dalam beberapa kuadran, yaitu: daerah cepat maju dan cepat tumbuh, daerah maju tapi tertekan, daerah berkembang pesat dan daerah relatif tertinggal.

Hasil analisis menggunakan tipologi klassen adalah ada tiga Kecamatan yang masuk dalam kategori daerah cepat maju dan tumbuh dikarenakan daerah tersebut merupakan daerah yang berperan sebagai pusat jalannya perekonomian di Jember, yaitu: Kaliwates, Sumbersari dan Patrang. Kecamatan Puger, Wuluhan, Ambulu, Tanggul, Bangsalsari dan Sumberbaru tergolong dalam kuadran I dikarenakan pertumbuhan PDRB di daerah tersebut naik terus. Sedangkan Kecamatan Panti menjadi satu-satunya daerah yang masuk dalam kategori daerah tertinggal karena tingkat ekonomi yang rendah. 
Published July 2019

EKONOMIKAWAN : Jurnal Ilmu Ekonomi dan Studi Pembangunan

ISSN : $1693-7600$ (Print), ISSN : 2598-0157 (Online), http://jurnal.umsu.ac.Id/index.php/ekawan

Tabel 3. Klasifikasi wilayah Per Kecamatan Berdasarkan Laju pertumbuhan dan Pendapatan Perkapita Kabupaten Jember Tahun 2014-2017

\begin{tabular}{|c|c|c|c|c|}
\hline Kuadran & 2014 & 2015 & 2016 & 2017 \\
\hline I & $\begin{array}{l}\text { Sumbersari } \\
\text { Kaliwates } \\
\text { Patrang } \\
\text { Wuluhan }\end{array}$ & $\begin{array}{l}\text { Sumbersari } \\
\text { Kaliwates } \\
\text { Patrang }\end{array}$ & $\begin{array}{l}\text { Sumbersari } \\
\text { Kaliwates } \\
\text { Patrang }\end{array}$ & $\begin{array}{l}\text { Sumbersari } \\
\text { Kaliwates } \\
\text { Patrang } \\
\text { Puger } \\
\text { Wuluhan } \\
\text { Ambulu } \\
\text { Bangsalsari } \\
\text { Sumberbaru } \\
\text { Tanggul }\end{array}$ \\
\hline II & $\begin{array}{l}\text { Rambipuji } \\
\text { Balung }\end{array}$ & $\begin{array}{l}\text { Rambipuji } \\
\text { Balung }\end{array}$ & Sukowono & $\begin{array}{l}\text { Semboro } \\
\text { Mumbulsari } \\
\text { Sumberjambe } \\
\text { Ledokombo } \\
\text { Sukowono } \\
\text { Ajung } \\
\text { Tempurejo } \\
\text { Kalisat } \\
\text { Umbulsari } \\
\text { Arjasa } \\
\text { Pakusari } \\
\text { Jelbuk } \\
\text { Kencong } \\
\text { Jenggawah } \\
\text { Gumukmas } \\
\text { Balung } \\
\text { Rambipuji } \\
\text { Silo } \\
\text { Jombang } \\
\text { Mayang } \\
\text { Sukorambi }\end{array}$ \\
\hline III & $\begin{array}{l}\text { Puger } \\
\text { Ambulu } \\
\text { Bangsalsari } \\
\text { Sumberbaru } \\
\text { Tanggul }\end{array}$ & $\begin{array}{l}\text { Puger } \\
\text { Ambulu } \\
\text { Bangsalsari } \\
\text { Sumberbaru } \\
\text { Tanggul } \\
\text { Wuluhan }\end{array}$ & $\begin{array}{l}\text { Puger } \\
\text { Ambulu } \\
\text { Bangsalsari } \\
\text { Sumberbaru } \\
\text { Tanggul } \\
\text { Wuluhan }\end{array}$ & - \\
\hline
\end{tabular}


Published July 2019

EKONOMIKAWAN : Jurnal Ilmu Ekonomi dan Studi Pembangunan

ISSN : $1693-7600$ (Print), ISSN : 2598-0157 (Online), http://jurnal.umsu.ac.Id/index.php/ekawan

\begin{tabular}{|c|c|c|c|c|}
\hline Kuadran & 2014 & 2015 & 2016 & 2017 \\
\hline \multirow{21}{*}{ IV } & Semboro & Semboro & Semboro & \multirow{21}{*}{ Panti } \\
\hline & Mumbulsari & Mumbulsari & Mumbulsari & \\
\hline & Sumberjambe & Sumberjambe & Sumberjambe & \\
\hline & Ledokombo & Ledokombo & Ledokombo & \\
\hline & Sukowono & Sukowono & Panti & \\
\hline & Panti & Panti & Tempurejo & \\
\hline & Tempurejo & Tempurejo & Kalisat & \\
\hline & Kalisat & Kalisat & Umbulsari & \\
\hline & Umbulsari & Umbulsari & Silo & \\
\hline & Silo & Silo & Balung & \\
\hline & Kencong & Kencong & Rambipuji & \\
\hline & Jenggawah & Jenggawah & Kencong & \\
\hline & Gumukmas & Gumukmas & Jenggawah & \\
\hline & Jombang & Jombang & Gumukmas & \\
\hline & Mayang & Mayang & Jombang & \\
\hline & Arjasa & Arjasa & Mayang & \\
\hline & Pakusari & Pakusari & Arjasa & \\
\hline & Sukorambi & Sukorambi & Pakusari & \\
\hline & Jelbuk & Jelbuk & Sukorambi & \\
\hline & Ajung & Ajung & Jelbuk & \\
\hline & & & Ajung & \\
\hline
\end{tabular}

Alat analisa DLQ pada penelitian di Kabupaten Jember pada tahun 2014-2017 menghasilkan data sebagai berikut:

Tabel 4. Hasil Analisa DLQ

\begin{tabular}{|c|c|c|}
\hline No & Kecamatan & $D L Q \geq 1$ \\
\hline 1 & Sumbersari & $\begin{array}{l}\text { - perdagangan, hotel dan restoran } \\
\text { - } \quad \text { keuangan, persewaan bangunan dan jasa perusahaan. }\end{array}$ \\
\hline 2 & Kaliwates & $\begin{array}{l}\text { - perdagangan, hotel dan restoran } \\
\text { - } \quad \text { keuangan, persewaan bangunan dan jasa perusahaan }\end{array}$ \\
\hline 3 & Patrang & $\begin{array}{ll}- & \text { perdagangan, hotel dan restoran } \\
-\quad & \text { jasa-jasa } \\
-\quad & \text { keuangan, persewaan dan jasa perusahaan } \\
-\quad & \text { pengangkutan dan komunikasi }\end{array}$ \\
\hline 4 & Puger & $\begin{array}{ll}- & \text { Bangunan } \\
-\quad & \text { industri pengelolahan } \\
- & \text { pertambangan dan penggalian pertanian }\end{array}$ \\
\hline 5 & Ambulu & $\begin{array}{l}\text { - jasa-jasa } \\
\text { - } \quad \text { pertambangan dan penggalian pertanian } \\
\text { - } \quad \text { bangunan }\end{array}$ \\
\hline 6 & Wuluhan & $\begin{array}{ll}- & \text { pertanian } \\
- & \text { industri pengelolahan } \\
-\quad & \text { bangunan } \\
-\quad & \text { pertambangan dan penggalian } \\
- & \text { listrik, gas dan air bersih }\end{array}$ \\
\hline 7 & Bangsalsari & $\begin{array}{ll}- & \text { pertanian } \\
- & \text { industri pengelolahan } \\
- & \text { listrik, gas dan air bersih } \\
-\quad & \text { pertambangan dan penggalian }\end{array}$ \\
\hline 8 & Sumberbaru & $\begin{array}{ll}- & \text { Pertanian } \\
-\quad & \text { pertambangan dan penggalian } \\
-\quad & \text { bangunan } \\
- & \text { listrik, gas dan air bersih }\end{array}$ \\
\hline 9 & Silo & $\begin{array}{ll}- & \text { bangunan } \\
- & \text { pertanian } \\
- & \text { pertambangan dan penggalian } \\
- & \text { pengangkutan dan komunikasi } \\
- & \text { listrik, gas dan air bersih } \\
- & \text { industri pengelolahan }\end{array}$ \\
\hline 10 & Tanggul & $\begin{array}{ll}- & \text { pengangkutan dan komunikasi } \\
- & \text { pertanian } \\
- & \text { pertambangan dan penggalian. }\end{array}$ \\
\hline
\end{tabular}




\section{Published July 2019}

EKONOMIKAWAN : Jurnal Ilmu Ekonomi dan Studi Pembangunan

ISSN : $1693-7600$ (Print), ISSN : 2598-0157 (Online), http://jurnal.umsu.ac.Id/index.php/ekawan

Tabel Lanjutan

\begin{tabular}{|c|c|c|}
\hline 11 & Rambipuji & $\begin{array}{ll}\text { - } & \text { industri pengelolahan } \\
\text { - } & \text { pengangkutan dan komunikasi } \\
\text { - } & \text { listrik, gas dan air bersih }\end{array}$ \\
\hline 12 & Balung & $\begin{array}{ll}\text { - } & \text { industri pengelolahan } \\
\text { - } & \text { jasa-jasa } \\
\text { - } & \text { pertambangan dan penggalian } \\
\text { - } & \text { listrik, gas dan air bersih } \\
\text { - } & \text { bangunan } \\
\text { - } & \text { pengangkutan dan komunikasi }\end{array}$ \\
\hline 13 & Gumukmas & $\begin{array}{l}\text { - } \quad \text { pertanian } \\
\text { - } \quad \text { pertambangan dan penggalian } \\
\text { - } \quad \text { listrik, gas dan air bersih }\end{array}$ \\
\hline 14 & Jenggawah & $\begin{array}{ll}\text { - } & \text { listrik, gas dan air bersih } \\
\text { - } & \text { pertanian } \\
\text { - } & \text { jasa-jasa } \\
\text { - } & \text { pengangkutan dan komunikasi } \\
\text { - } & \text { industri pengolahan } \\
\text { - } & \text { pertambangan dan penggalian }\end{array}$ \\
\hline 15 & Kencong & $\begin{array}{ll}\text { - } & \text { pertanian } \\
\text { - } & \text { pertambangan dan penggalian } \\
\text { - } & \text { listrik, gas dan air bersih } \\
\text { - } & \text { bangunan } \\
\text { - } & \text { pengangkutan dan komunikasi } \\
\text { - } & \text { keuangan, persewaan dan jasa perusahaan } \\
\text { - } & \text { jasa-jasa }\end{array}$ \\
\hline 16 & Umbulsari & $\begin{array}{ll}\text { - } & \text { pertanian } \\
\text { - } & \text { pertambangan dan penggalian } \\
\text { - } & \text { listrik, gas dan air bersih }\end{array}$ \\
\hline 17 & Kalisat & $\begin{array}{ll}\text { - } & \text { pertanian } \\
\text { - } & \text { pertambangan dan penggalian } \\
\text { - } & \text { industri pengelolahan } \\
\text { - } & \text { listrik, gas dan air bersih } \\
\text { - } & \text { bangunan } \\
\text { - } & \text { pengangkutan dan komunikasi, jasa-jasa }\end{array}$ \\
\hline 18 & Panti & $\begin{array}{ll}\text { - } & \text { pertanian } \\
\text { - } & \text { keuangan, persewaan dan jasa perusahaan } \\
\text { - } & \text { bangunan } \\
\text { - } & \text { industri pengelolahan }\end{array}$ \\
\hline 19 & Ajung & $\begin{array}{ll}\text { - } & \text { pertanian } \\
\text { - } & \text { listrik, gas dan air bersih } \\
\text { - } & \text { pertambangan dan penggalian } \\
\text { - } & \text { keuangan, persewaan dan jasa perusahaan }\end{array}$ \\
\hline 20 & Tempurejo & $\begin{array}{ll}\text { - } & \text { pertanian } \\
\text { - } & \text { pertambangan dan penggalian } \\
\text { - } & \text { listrik, gas dan air bersih } \\
\text { - } & \text { bangunan }\end{array}$ \\
\hline 21 & Sukowono & - Dertanian \\
\hline
\end{tabular}




\section{Published July 2019}

EKONOMIKAWAN : Jurnal Ilmu Ekonomi dan Studi Pembangunan

ISSN : $1693-7600$ (Print), ISSN : 2598-0157 (Online), http://jurnal.umsu.ac.ld/index.php/ekawan

Tabel Lanjutan .

\begin{tabular}{|c|c|c|}
\hline 22 & Ledokombo & $\begin{array}{ll}\text { - } & \text { Pertanian } \\
\text { - } & \text { pertambangan dan penggalian } \\
\text { - } & \text { bangunan } \\
\text { - } & \text { listrik, gas dan air bersih }\end{array}$ \\
\hline 23 & Sumberjambe & $\begin{array}{ll}\text { - } & \text { pertanian } \\
\text { - } & \text { pertambangan dan penggalian } \\
\text { - } & \text { listrik, gas dan air bersih, bangunan }\end{array}$ \\
\hline 24 & Mumbulsari & $\begin{array}{ll}\text { - } & \text { pertanian } \\
\text { - } & \text { Bangunan } \\
\text { - } & \text { pertambangan dan penggalian } \\
\text { - } & \text { listrik, gas dan air bersih }\end{array}$ \\
\hline 25 & Semboro & - pertanian \\
\hline 26 & Jombang & 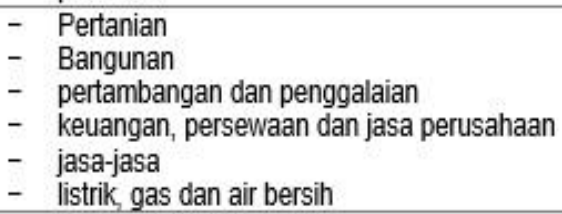 \\
\hline 27 & Mayang & $\begin{array}{ll}\text { - } & \text { pertanian } \\
\text { - } & \text { bangunan } \\
\text { - } & \text { pertambangan dan penggalian } \\
\text { - } & \text { listrik, gas dan air bersih }\end{array}$ \\
\hline 28 & Arjasa & $\begin{array}{ll}\text { - } & \text { pertanian } \\
\text { - } & \text { listrik, gas dan air bersih } \\
\text { - } & \text { pengangkutan dan komunikasi }\end{array}$ \\
\hline 29 & Pakusari & $\begin{array}{ll}\text { - } & \text { listrik, gas dan air bersih } \\
\text { - } & \text { pertambangan dan penggalian } \\
\text { - } & \text { bangunan } \\
\text { - } & \text { pertanian }\end{array}$ \\
\hline 30 & Sukorambi & $\begin{array}{ll}\text { - } & \text { Bangunan } \\
\text { - } & \text { Pertanian } \\
\text { - } & \text { listrik, gas dan air bersih }\end{array}$ \\
\hline 31 & Jelbuk & $\begin{array}{l}\text { - listrik, gas dan air bersih } \\
\text { - } \\
\text { - } \\
\text { industrian pengelolahan }\end{array}$ \\
\hline
\end{tabular}

Analisis DLQ merupakan alat yang digunakan untuk mengetahui apakah di masa depan sektor yang sekarang basis dan non basis nantinya akan berubah menjadi sektor basis atau non basis. Sektor basis yang paling memiliki pertumbuhan cepat adalah sektor pertanian. Sektor basis pada Kecamatan Puger, Kencong, Silo, Sukowono, Mumbulsari, Mayang, Jombang, Pakusari dan Sukorambi memiliki nilai paling tinggi adalah sektor bangunan.

Analisis SSEM merupakan analisis yang berguna untuk mengetahui sektor yang memiliki spesialisasi dan keunggulan kompetitif yang menghasilkan data pada tabel 5 . Hasil analisis tersebut menyatakan bahwa terdapat 7 sektor di Kecamatan Jombang yang memiliki keunggulan kompetitif. Sektor pertanian menjadi sektor yang paling dominan dikarenakan memiliki keunggulan kompetitif di 31 Kecamatan yang ada di Kabupaten Jember. 
Published July 2019

EKONOMIKAWAN : Jurnal Ilmu Ekonomi dan Studi Pembangunan

ISSN : $1693-7600$ (Print), ISSN : 2598-0157 (Online), http://jurnal.umsu.ac.ld/index.php/ekawan

Tabel 5 : Rata-Rata Hasil Analisis SSEM Spesialisasi dan Keunggulan Kompetitif Per Kecamatan Kabupaten Jember Tahun 2014-2017

\begin{tabular}{|c|c|c|c|}
\hline No & Kecamatan & Spesialisasi & Keunggulan Kompetitif \\
\hline 1 & Sumbersari & $1-9$ & $3,5,6,7,8,9$ \\
\hline 2 & Kaliwates & $1-9$ & $1,6,7,8,9$ \\
\hline 3 & Patrang & $1-9$ & $4,6,7$ \\
\hline 4 & Puger & $1-9$ & $3,6,8$ \\
\hline 5 & Ambulu & $1-9$ & $1,3,6$ \\
\hline 6 & Wuluhan & $1-9$ & $2,3,4,6,8,9$ \\
\hline 7 & Bangsalsari & $1-9$ & $3,5,6,9$ \\
\hline 8 & Sumberbaru & $1-9$ & $2,6,8$ \\
\hline 9 & Silo & $1-9$ & $1,5,6,7,9$ \\
\hline 10 & Tanggul & $1-9$ & $4,5,6,7,8,9$ \\
\hline 11 & Rambipuji & $1-9$ & $2,3,6,8,9$ \\
\hline 12 & Balung & $1-9$ & $1,2,7,8$ \\
\hline 13 & Gumukmas & $1-9$ & $1,4,5,6$ \\
\hline 14 & Jenggawah & $1-9$ & $2,6,7,9$ \\
\hline 15 & Kencong & $1-9$ & $1,3,4,6,7$ \\
\hline 16 & Umbulsari & $1-9$ & $1,3,4,9$ \\
\hline 17 & Kalisat & $1-9$ & $1,5,9$ \\
\hline 18 & Panti & $1-9$ & $3,5,6,8$ \\
\hline 19 & Ajung & $1-9$ & $7,8,9$ \\
\hline 20 & Tempurejo & $1-9$ & $1,2,7,9$ \\
\hline 21 & Sukowono & $1-9$ & $1,2,3,4,6,8$ \\
\hline 22 & Ledokombo & $1-9$ & $3,6,7$ \\
\hline 23 & Sumberjambe & $1-9$ & 2,3 \\
\hline 24 & Mumbulsari & $1-9$ & $1,7,8,9$ \\
\hline 25 & Semboro & $1-9$ & $1,2,3,4,6,7$ \\
\hline 26 & Jombang & $1-9$ & $1,2,3,4,5,7,9$ \\
\hline 27 & Mayang & $1-9$ & $3,4,5,7$ \\
\hline 28 & Arjasa & $1-9$ & $2,4,5,9$ \\
\hline 29 & Pakusari & $1-9$ & $6,7,8$ \\
\hline 30 & Sukorambi & $1-9$ & $3,6,7,8,9$ \\
\hline 31 & Jelbuk & $1-9$ & $2,4,6,9$ \\
\hline
\end{tabular}

Keterangan :

Kode 1 : Pertanian

Kode 2 : Pertambangan \& Penggalian

Kode 3 : Indudtri Pengelolahan

Kode 4 : Listrik, Gas \& Air Bersih

Kode 5 : Bangunan

Kode 6 : Perdagangan, Hotel \& Restoran

Kode 7 : Pengangkutan \& Komunikasi

Kode 8 : Keuangan, Persewaan \& Jasa Perusahaan

Kode 9 : Jasa-Jasa 
Published July 2019

EKONOMIKAWAN : Jurnal Ilmu Ekonomi dan Studi Pembangunan

ISSN : 1693-7600 (Print), ISSN : 2598-0157 (Online), http://jurnal.umsu.ac.Id/index.php/ekawan

\section{Pembahasan}

Menurut Blakely E.J (1994), pembangunan ekonomi adalah proses pengolahan dan perkembangan sumber daya alam dalam rangka perluasan lapangan kerja dengan tujuan peningkatan pertumbuhan ekonomi yang dilakukan oleh pemerintah daerah dan masyarakat. Perencanaan pembangunan membutuhkan pengklasifikasian wilayah untuk dapat mengetahui karakter dari wilayah tersebut (Soetriono dan Wibowo, 2002:57). Agar pengklasifikasian wilayah tersebut lancar maka penelitian memerlukan dukungan analisis tipologi klassen berdasarkan indikator laju pertumbuhan ekonomi (sumbu vertikal) dan PDRB (sumbu horizontal) (Sjafrizal, 2008:180). Pengklasifikasian berdasarkan kedua indikator tersebut memiliki kriteria apabila Yi lebih besar dari y dan Ri lebih besar dari $r$ maka daerah tersebut masuk dalam kategori kuadran I yang merupakan daerah maju dan tumbuh cepat; dan sebaliknya apabila Yi lebih kecil dari y dan Ri lebih besar dari r maka daerah tersebut masuk dalam kategori kuadran II yang merupakan daerah maju tapi tertekan. Kriteria selanjutnya jika Yi lebih besar dari y dan Ri lebih kecil dari r maka daerah tersebut masuk dalam kuadran III yang berarti daerah berkembang cepat dan yang terakhir apabila Yi lebih kecil dari y dan Ri lebih kecil dari r maka masuk dalam kategori kuadran IV yang merupakan daerah relatif tertinggal.

Analisis tipologi klassen dalam penelitian ini membagi daerah yang diteliti ke dalam empat kuadran dengan objek penelitian 31 Kecamatan di Kabupaten Jember dengan periode penelitian selama 4 tahun yang dimulai dari tahun 2014 sampai 2017. Hasil penelitian ini menunjukkan bahwa secara keseluruhan Kecamatan Kaliwates, Sumbersari dan Patrang masuk dalam kategori kuadran I yaitu daerah cepat maju dan cepat tumbuh dikarenakan ketiga daerah tersebut merupakan pusat dari seluruh kegiatan ekonomi di Kabupaten Jember. Pada tahun 2014 daerah yang masuk dalam kategori I bertambah dikarenakan kedua indikator yang digunakan yaitu laju pertumbuhan dan PDRB mengalami kenaikan. Daerah yang masuk dalam kategori kuadran I tersebut adalah Kecamatan Puger Wuluhan, Ambulu, Tanggul, Bangsalsari dan Sumberbaru. Di samping banyaknya Kecamatan yang masuk dalam kategori kuadran I, ada satu daerah yang masih masuk dalam kategori kuadran IV yaitu Kecamatan Panti.

Kecamatan Sumberbaru, Kaliwates dan Patrang merupakan daerah yang masuk dalam kategori daerah kuadran I setiap tahunnya dari 2014 hingga 2017 dikarenakan ketiga daerah tersebut adalah pusat kota yang berperan sebagai sarana kegiatan ekonomi masyarakat Kabupaten Jember sehingga mampu berkembang dengan sendirinya (BPS, 2013). Ketiga daerah tersebut diberlakukan kebijakan penataan ruang agar dapat menjaga kestabilan dari pertumbuhan ekonomi yang terus meningkat sehingga akan merangsang daerah lain untuk mengembangkan daerahnya. Kebijakan tersebut diharapkan membantu dalam meratakan pertumbuhan sehingga terciptanya pembangunan ekonomi secara nasional. Kebijakan penataan ruang diterapkan berdasarkan adanya potensi yang dapat dikembangkan kedepannya di setiap daerah.

Analisis DLQ selain berfungsi menentukan mana yang masuk dalam kategori basis dan non basis juga dapat mengetahui kinerja sektor perekonomian tiap Kecamatan yang ada di Kabupaten Jember. Kriteria dari analisis DLQ adalah apabila DLQ lebih besar dari 1 maka dapat diharapkan tetap menjadi sektor basis di masa depan dan sebaliknya jika kurang dari 1 maka tidak dapat menjadi sektor basis di masa depan (Suyanto, 2000). 
Published July 2019

EKONOMIKAWAN : Jurnal Ilmu Ekonomi dan Studi Pembangunan

ISSN : $1693-7600$ (Print), ISSN : 2598-0157 (Online), http://jurnal.umsu.ac.Id/index.php/ekawan

Sektor bangunan berdasarkan analisis DLQ merupakan sektor yang memiliki nilai basis tertinggi di Kecamatan Puger, Kencong, Silo, Sukowono, Mumbulsari, Mayang, Jombang, Pakusari dan Sukorambi. Sedangkan sektor pertanian akan lebih diutamakan pada masa depan karena mendominan di seluruh Kecamatan di Kabupaten Jember. Sekor pertanian memiliki potensi yang dapat dikembangkan dan berperan membantu dalam perekonomian daerah di masa depan. Tetapi lambat laun sektor pertanian mengalami penurunan dikarenakan perkembangan yang terjadi pada sektor lain, khususnya sektor bangunan yang berperan sebagai penopang infrastuktur. Sektor bangunan memiliki pasar yang luas dan kuat dikarenakan pembangunan perumahan, pertokoan, hotel serta proyekproyek perbaikan jalan dan fasilitas umum yang dilakukan swasta dan pemerintah. Pertumbuhan sektor bangunan tidak lepas dari peran sektor pertanian yang dapat membantu pertumbuhan sektor lainnya (RKPD Kabupaten Jember, 2015).

Tabel 6 : Matriks Gabungan antara Tiga Metode analisis (Tipologi Klassen, DLQ dan

SSEM) Per Kecamatan Kabupaten Jember

\begin{tabular}{|c|c|c|c|c|c|}
\hline \multirow[t]{2}{*}{ No } & \multirow[t]{2}{*}{ Kecamatán } & \multirow[t]{2}{*}{$\begin{array}{l}\text { Tipologi } \\
\text { Klassen }\end{array}$} & \multirow[t]{2}{*}{ DLQ } & SSEM & \multirow[t]{2}{*}{ Keunggulan Kompetitif } \\
\hline & & & & Spesialisasi & \\
\hline 1 & Sumbersari & I & 6,8 & $1-9$ & $3,5,6,7,8,9$ \\
\hline 2 & Kaliwates & I & 6,8 & $1-9$ & $1,6,7,8,9$ \\
\hline 3 & Patrang & I & $6,7,8,9$ & $1-9$ & $4,6,7$ \\
\hline 4 & Puger & III & $2,3,5$ & $1-9$ & $3,6,8$ \\
\hline 5 & Ambulu & III & $2,5,9$ & $1-9$ & $1,3,6$ \\
\hline 6 & Wuluhan & III & $1,2,3,4,5$ & $1-9$ & $2,3,4,6,8,9$ \\
\hline 7 & Bangsalsari & III & $1,2,3,4$ & $1-9$ & $3,5,6,9$ \\
\hline 8 & Sumberbaru & III & $1,2,4,5$ & $1-9$ & $2,6,8$ \\
\hline 9 & Silo & IV & $1,2,3,4,5,7$ & $1-9$ & $1,5,6,7,9$ \\
\hline 10 & Tanggul & III & $1,2,7$ & $1-9$ & $4,5,6,7,8,9$ \\
\hline 11 & Rambipuji & II & $2,4,7$ & $1-9$ & $2,3,6,8,9$ \\
\hline 12 & Balung & II & $2,3,4,5,7,9$ & $1-9$ & $1,2,7,8$ \\
\hline 13 & Gumukmas & IV & $1,2,4$ & $1-9$ & $1,4,5,6$ \\
\hline 14 & Jenggawah & IV & $1,2,3,4,7,9$ & $1-9$ & $2,6,7,9$ \\
\hline 15 & Kencong & IV & $1,2,4,5,7,8,9$ & $1-9$ & $1,3,4,6,7$ \\
\hline 16 & Umbulsari & IV & $1,2,4$ & $1-9$ & $1,3,4,9$ \\
\hline 17 & Kalisat & IV & $1,2,3,4,5,7$ & $1-9$ & $1,5,9$ \\
\hline 18 & Panti & IV & $1,3,5,8$ & $1-9$ & $3,5,6,8$ \\
\hline 19 & Ajung & IV & $1,2,4,8$ & $1-9$ & $7,8,9$ \\
\hline 20 & Tempurejo & IV & $1,2,4,5$ & $1-9$ & $1,2,7,9$ \\
\hline 21 & Sukowono & IV & $1,2,4,5,6$ & $1-9$ & $1,2,3,4,6,8$ \\
\hline 22 & Ledokombo & IV & $1,2,5$ & $1-9$ & $3,6,7$ \\
\hline 23 & Sumberjambe & IV & $1,2,4$ & $1-9$ & 2,3 \\
\hline 24 & Mumbulsari & IV & $1,2,4,5$ & $1-9$ & $1,7,8,9$ \\
\hline 25 & Semboro & IV & 1 & $1-9$ & $1,2,3,4,6,7$ \\
\hline 26 & Jombang & IV & $1,2,4,5,8,9$ & $1-9$ & $1,2,3,4,5,7,9$ \\
\hline 27 & Mayang & IV & $1,2,4,5$ & $1-9$ & $3,4,5,7$ \\
\hline 28 & Arjasa & IV & $1,4,7$ & $1-9$ & $2,4,5,9$ \\
\hline 29 & Pakusari & IV & $1,2,4,5$ & $1-9$ & $6,7,8$ \\
\hline 30 & Sukorambi & IV & $1,4,5$ & $1-9$ & $3,6,7,8,9$ \\
\hline 31 & Jelbuk & IV & $1,3,4$ & $1-9$ & $2,4,6,9$ \\
\hline
\end{tabular}

Keterangan:

Kode 1 : Pertanian

Kode 2 : Pertambangan \& Penggalian

Kode 3 : Indudtri Pengelolahan

Kode 4 : Listrik, Gas \& Air Bersih

Kode 5 : Bangunan 
Published July 2019

EKONOMIKAWAN : Jurnal Ilmu Ekonomi dan Studi Pembangunan

ISSN : $1693-7600$ (Print), ISSN : 2598-0157 (Online), http://jurnal.umsu.ac.ld/index.php/ekawan

\author{
Kode 6 : Perdagangan, Hotel \& Restoran \\ Kode 7 : Pengangkutan \& Komunikasi \\ Kode 8 : Keuangan, Persewaan \& Jasa Perusahaan \\ Kode 9 : Jasa-Jasa
}

Analisis SSEM dalam penelitian ini digunakan untuk mengetahui spesialisasi dan keunggulan kompetitif dari sektor tertentu pada suatu wilayah. Hasil penelitian menggunakan analisis SSEM menunjukkan terdapat 9 sektor ekonomi yang memiliki spesialisasi dan keunggulan kompetitif. Kecamatan Jombang merupakan satu-satunya daerah yang memiliki 7 sektor dengan keunggulan kompetitif. Sektor pertanian merupakan sektor yang dominan dengan keunggulan kompetitif.

Ketiga analisis digabungkan menjadi satu sehingga menghasilkan bahwa sektor setiap Kecamatan memiliki klasifikasi wilayah, sektor berpotensi di masa depan dan keunggulan kompetitif serta spesialisasi. Selain itu, sektor bangunan merupakan sektor yang memiliki nilai DLQ tertinggi sedangkan sektor yang dominan di semua daerah adalah sektor pertanian. Kecamatan Jombang berdasar analisis SSEM merupakan daerah dengan sektor ekonomi yang memiliki keunggulan kompetitif terbanyak.

\title{
SIMPULAN
}

Hasil penelitian dari ketiga analisis menghasilkan kesimpulan sebagai berikut:

1. Berdasarkan analisa tipologi klassen, Kecamatan yang masuk kategori kuadran I adalah Kecamatan Puger Wuluhan, Ambulu, Tanggul, Bangsalsari dan Sumberbaru. Kecamatan Panti menjadi satu-satunya Kecamatan yang masuk dalam kategori kuadran IV.

2. Berdasarkan analisa DLQ, sektor pertanian menjadi sektor yang dapat diutamakan di masa depan karena memiliki potensi yang dapat dikembangkan sedangkan sektor yang memiliki peringkat tertinggi adalah sektor bangunan.

3. Berdasarkan analisa SSEM, Kecamatan Jombang memiliki 7 sektor yang memiliki keunggulan kompetitif sedangkan sektor pertanian menjadi sektor yang dominan dikarenakan satu-satunya yang dimiliki Kecamatan dengan keunggulan kompetitif.

\section{DAFTAR PUSTAKA}

\section{Buku :}

Adisasmita, R. 2005. Dasar-Dasar Ekonomi Wilayah. Graha Ilmu. Yogyakarta.

Arsyad, Lincolin. 1999. Pengantar Perencanaan dan Pembangunan Ekonomi Daerah. Yogyakarta: BPFE.

Badan Pusat Statistika Kabupaten Jember. 2017. PDRB Kabupaten Jember dalam Angka. Jember: Badan Pusat Statistika Kabupaten Jember.

Badan Pusat Statistika Kabupaen Jember. 2017. PDRB Kecamatan Kabupaten Jember dalam Angka. Jember: Badan Pusat Statistika Kabupaten Jember

Blakely, Edward J. 1994. City Planning Local Economic Deveploment: Theory and Practice. California: Sage Publications, Inc.

Budiharsono, S. 2001. Teknik Analisis Pembangunan Wilayah Pesisir dan Lautan. Pradnya. Paramitha. Jakarta.

Indriantoro, Nur dan Bambang Supomo.1999. Metode Penelitian Bisnis untuk Akuntansi dan Manajemen. Cetakan Ketiga. BPFE. Yogyakarta. 
Published July 2019

EKONOMIKAWAN : Jurnal Ilmu Ekonomi dan Studi Pembangunan

ISSN : 1693-7600 (Print), ISSN : 2598-0157 (Online), http://jurnal.umsu.ac.id/index.php/ekawan

Richardson, H. W. 1991. Dasar-dasar Ilmu Ekonomi Regional (Terjemahan) LPFE UI. Jakarta.

Sjafrizal, 1997. "Pertumbuhan Ekonomi Dan Ketimpangan Regional Wilayah Indonesia Bagian Barat”. Prisma, No.3. Hal:27-38.

2008. Ekonomi Regional, Teori dan Aplikasi (cetakan pertama). Padang: Baduose Media.

Soekartawi. 1996. Pembangunan Pertanian untuk Mengentas Kemiskinan. UIPress. Jakarta.

Soetriono dan Wibowo, R. 2002. Konsep dan landasan analisis wilayah. Jember: Fakultas pertanian Universitas Jember.

Sugiyono. 2012. Metode Penelitian Kuantitatif Kualitatif dan R\&D. Bandung: Alfabeta.

Sukirno, Sadono. 2006. Ekonomi Pembangunan: Proses, Masalah, dan Dasar Kebijakan. Jakarta: Kencana Prenada Media Group.

Tarigan, Robinson. 2005. Perencanaan Pembangunan Wilayah (edisi revisi).Jakarta: Bumi Aksara.

, 2007. Ekonomi Regional, Teori dan Aplikasi, PT. Bumi Aksara, Cetakan Keempat, Jakarta.

Todaro P. Michael. 2000. Pembangunan Ekonomi di Dunia Ketiga Jilid 1. Jakarta Penerbit: Erlangga.

Universitas Jember. 2010. Pedoman Penulisan Karya Ilmiah. Jember University Press. Jember: Badan Penerbit Universitas Jember

Widodo, Tri. 2006. Perencanaan Pembangunan: Aplikasi Komputer (Era Otonomi Daerah). UPP STIM YKPN Yogyakarta.Yogyakarta.

\section{Jurnal:}

Andy, Andreas. 2014. Analisis Sektor Potensial dan Pengembangan Wilayah Kab/Kota (Study kasus Provinsi Daerah Istimewa Yogyakarta). Jurnal Ekonomi Pembangunan. [Februari 2015].

Aswandi, H, \& Kuncoro, M, 2002. Evaluasi Penetapan Kawasan Andalan : Studi Empiris di Kalimantan Selatan 1993-1999. Jurnal Ekonomi dan Bisnis Indonesia. Vol.17 (1):27-45. [Februari 2015].

Badrudin, Rudy. 2012. Pengembangan Ekonomi Lokal Kabupaten/Kota Provinsi Daerah Istimewa Yogyakarta Menggunakan Tipologi Klassen dan Location Quotient. Jurnal Ekonomi Pembangunan. Vol.7(1):17-34. [Februari 2015].

Basuki, Tri, Agus \& Gayatri, Utari. 2009. Penentuan Sektor Unggulan Dalam Pembangunana Daerah (Study Kasus di Kabupaten Ogan Komering Ilir). Jurnal Ekonomi dan Studi PembangunanUniversitas Muahammadiyah Yogyakarta. Vol 10 (1):34-50. [Februari 2015].

Elia, Radianto. 2003. Evaluasi Pembangunan Regional Pasca Kerusuhan di Maluku. Jurnal Ekonomi dan Keuangan Indonesia. Vol.51 (4):479-499. [Februari 2015].

Firmansyah, Risky.2013. Analisis Penentuan Sektor Unggulan Perekonomian dengan Metode Analytical Hierarchy Process (AHP) dan Shift Share Terhadap Pertumbuhan Ekonomi (Studi Kota Malang). Jurnal Ekonomi dan Bisnis Universitas Brawijaya. Vol.30 (1). [Februari 2015]. 


\section{Published July 2019}

EKONOMIKAWAN : Jurnal Ilmu Ekonomi dan Studi Pembangunan

ISSN : 1693-7600 (Print), ISSN : 2598-0157 (Online), http://jurnal.umsu.ac.id/index.php/ekawan

Haris, Zulfi. 2012. Analisis Penentuan Sektor/Subsektor Unggulan dan Kaitannya dengan Perencanaan Pembangunan Ekonomi Kabupaten Lampung Utara. Tesis Ekonomi Universitas Indonesia Jakarta. [Februari 2015].

Permana, A. A. 2014. Analisis Sektor Potensial dan Pengembangan Wilayah Kabupaten/Kota (Studi Kasus Provinsi Daerah Istimewa Yogyakarta Periode 20072012). Jurnal Ilmu Ekonomi dan Bisnis Universitas Brawijaya Malang. [Februari 2015].

Rumayar, Monalisa. 2009. Pentingkah Perencanaan Pembangunan itu. [Februari 2015].

Soepono, Prasetyo. "Analisis Shift-share: Perkembangan dan Penerapan”. Jurnal Ekonomi dan Bisnis Indonesia, BPFE, Yogyakarta. [Februari 2015].

Suyatno. 2000. Analisis Economic Base Terhadap Pertumbuhan Ekonomi Daerah Tingkat II wonogirl: Menghadapi Implementasi UU No.22/1999 dan UU No.5/1999. Jurnal Ekonomi Pembangunan Universitas Muhammadiyah Surakarta.Vol.I (2). Desember 2000:144-159. [Februari 2015].

Tristanto, A. H. 2013. Analisis Sektor Ekonomi Unggulan dalam Pengembangan Potensi Perekonomian di Kota Blitar. Jurnal Ilmu Ekonomi dan Bisnis Universitas Brawijaya Malang. [Februari 2015]. 